\title{
Density of Insect Galls in the Forest Understorey and Canopy: Neotropical, Gondwana or Global Patterns?
}

\author{
Sérvio Pontes Ribeiro, Yves Basset,and Roger Kitching
}

\begin{abstract}
Gall-forming insects reach highest diversity, abundance and survivorship on sclerophyllous vegetation. This pattern was recently reviewed and shown as a habitat rather than ecosystem effect. We tested the hypothesis that upper forest canopies are probably the best suitable habitat for gall-forming insects in any tropical vegetation, comparing the wet rainforest of Panama (Neotropical), and the subtropical forest of Australia (Australian). We further tested whether foliage/plant community traits could influence this gall distribution pattern, and we investigated the effect of host family size and evolutionary age. Foliage traits, leaf chewing herbivory, and gall abundance and survivorship were measured using vertical cylindric transects from the understorey to the canopy. In both Panama and Australia, leaf sclerophylly increased signifi cantly with sampling height, while free-feeding herbivory decreased inversely. Gall distribution and survivorship responded significantly to sclerophylly, but distribution between understorey and canopy varied between study sites. The probability of gall survivorship increased with increasing leaf sclerophylly as death by fungi, parasitoids or accidental chewing were greater in the non-sclerophyllous vegetation in the understorey of both study sites. However, number of galls, proportion of infected sampled plants, and proportion of host species against total sampled species were all greater in Panamá than in Australia.
\end{abstract}

\author{
S.P. Ribeiro $(\bowtie)$ \\ Laboratory of Evolutionary Ecology of Canopy Insects, \\ Department of Biodiversity, Evolution and Environment/ICEB, \\ Universidade Federal de Ouro Preto, Ouro Preto, MG, Brazil \\ e-mail: spribeiro@iceb.ufop.br \\ Y. Basset \\ Smithsonian Tropical Research Institute, Panama City, Republic of Panama \\ e-mail: bassety@si.edu \\ R. Kitching \\ Griffith School of the Environment, Griffith University, \\ Nathan, Queensland 4111, Australia \\ e-mail: r.kitching@griffith.edu.au
}


On the other hand, the Australian forest had a fauna much more concentrated on fewer hosts, with $80 \%$ of galls infesting six host species. The present study supports the existence of a global positive effect of sclerophylly on gall establishment and survivorship in the upper canopy of tropical and subtropical forests.

Keywords Canopy $\bullet$ Gall density $\bullet$ Leaf herbivory $\bullet$ Sclerophyllous habitats $\bullet$ Forest vertical distribution

\subsection{Introduction: Galls in Forests}

Galls are well known endoparasitic specialist herbivores related to highly sclerophyllous plants, thus a typical sun-love interaction. Seminal work of Fernandes and Price $(1988,1992)$ demonstrated that differential death by fungi and parasites, greater in shadowed and mesic compared to sunny and xeric sclerophyllous vegetations, is a likely mechanism driving the gall species distribution pattern. More recently, Mendonça (2001) added an evolutionary layer to this debate, proposing an ingenious evolutionary mechanism to explain the diversification of gall species based on the ecosystem-level synchrony of leaf flush. He predicted increasing speciation rates due to insect survival after mistaken oviposition, a likely event if all plants produce young leaves at the same time and insects have early oviposition to avoid hard tissues and thus facilitate the development of the gall tumour. Mendonça's hypothesis complements the harsh environment (Fernandes and Price 1988) and sclerophylly hypotheses (Fernandes and Price 1992). The former explains a mechanism of speciation and the latter of survivorship in sclerophyllous synchronous ecosystems. When considered together, these hypotheses help to explain why the highest gall diversity occurs in the Mediterranean-type vegetations, like the Brazilian cerrado (Price et al. 1998).

However, recent studies on gall diversity in Panama have shown a substantially larger number of galls in the canopy of tropical forests than in any other ecosystem, bringing to evidence a previously unexpected relation of this unique interaction with a very wet ecosystem. Furthermore, a significant amount of this diversity was detected by a yearly sampling protocol which measured the variation in gall species richness and abundance following each host-plant's leaf-flush (Medianero and Barrios 2001; Medianero et al. 2003). In Panama, no synchrony of leaf flush was observed at all, but gall diversity was among the highest ever found, thus contradicting the predictions of Mendonça (2001).

On the other hand, comparative analyses of the distribution of galls between xeric (upper canopy) and mesic (understorey) habitats within the forest seem to corroborate Fernandes and Price's (1992) prediction: a positive gradient between gall diversity and vegetation sclerophylly may exist. Nevertheless, even though the accepted mechanism to explain greater gall mortality in mesic over xeric habitats is apparently correct at the branch/leaf scale (Ribeiro and Basset 2007), it was first developed based on of a comparison between forest understorey and cerrado 
canopies, thus lack a proper vegetation-habitat control (reviewed in Ribeiro 2003). Indeed, Medianero et al. (2003, 2010) found that a humid closed rainforest on the Caribbean coast of Panama (San Lorenzo Protected Area) was richer in gall species than the dry semi-deciduous forest on the Panamanian Pacific coast (Parque Metropolitano). Mostly important, both forests were richer in galls in the canopy than in the understorey. Hence, the actual eco-physiology of the habitat (forest understorey vs. cerrado canopy) within which the galls live is more relevant to the pattern than the existence of a mesic or xeric state of the plant community as a whole. Hence, the present global estimate of 130,000 gall species from Espírito-Santo and Fernandes (2007), although accounting for previous bias in the literature, such as lesser studies in the canopies than in easier accessible vegetation in temperate or tropical latitudes, may have missed within-ecosystem habitats comparisons.

Despite the positive response to sclerophyllous habitats, wherever galls occur, they are restricted to very few host species (Espírito-Santo and Fernandes 2007; Ribeiro and Basset 2007). Why so few plant taxa across biomes are suitable hosts for gall species is so far an unanswered question. For instance, Ribeiro and Basset (2007) observed galls on few tree species (22\% out of 73 tree/liana sampled species), from which $50 \%$ had congenerics or were also found (31\%) in the Brazilian cerrado. Both Price (1977) and Fernandes (1992) have proposed that gall diversity follows plant family size, but neither of these authors actually discussed evolutionary constraints to gall species distribution related to the life history of the host. Likewise, little have been done in order to understand what are the actual constraints to gall invasion success into most of host taxonomic groups, neither if this is a recent or old evolutionarily phenomena:

- how much of the Neotropical gall diversity resulted from local adaptive radiation in association with continuous sclerophyllous habitats, thus with wide and abundant host species distribution? Conversely,

- how much of such biodiversity was caused by an older Gondwana evolutionary history, which may influences gall species distribution in Neotropical, Cape Africa or Australasian regions?

This chapter revisited previous data obtained by the canopy-understorey cylinder transects protocol (Ribeiro and Basset 2007; Ribeiro et al. 2012), and add a new analytical approach in comparing the gall abundance distribution and survivorship between understorey and canopy of (a) a Neotropical wet rainforest, in Panama; and (b) an Australian subtropical rainforest (part of the Gondwana Rainforests of Australia), in Queensland. We explore the hypothesis that sclerophylly effect on gall distribution, previously demonstrated in the Neotropical region, is a general phenomenon, likely to be found in other regions, and is more important than other ecologic or evolutionary causes of gall abundance and distribution. Hence, besides testing the effect of leaf height and sclerophylly on gall distribution, we compared the forests foliage density and vertical distribution. In addition, we investigated whether gall diversity is restricted to few host species that belong to large pantropical or pre-Gondwana plant families. 


\subsection{Methodology}

The IBISCA Project and global comparisons in insect diversity - IBISCA (Investigating Biodiversity of Insects in Soil and Canopy) is an international project with the goal of performing simultaneously several arthropod sampling protocols, targeting particular speciose taxonomic groups, and yielding adequate data to compare the fauna from the soil to the canopy (details in Basset et al. 2007, 2012; Kitching et al. 2012). So far, expeditions were conducted in San Lorenzo Protected Area, Panama, Lamington Park, Australia, Santo Island, Vanuatu, and Auvergne County, France.

This Chapter focus on San Lorenzo and Lamington Park. Details on each study site and methodology are found in Basset et al. (2007), Ribeiro and Basset (2007), Kitching et al. (2012) and Ribeiro et al. (2012). To study galls, parasites and herbivory, a new methodology was developed, which generates a comparable number of searched leaves in same space volume from top canopy to understorey. Such procedure, the canopy-understorey pin-cylinder transect (hereafter cylinder; Ribeiro and Basset 2007), allows a direct comparison of different forests by using a same volumetric sample unit. A different amount of understorey-canopy cylinders were set in each study site to adjust to the general sampling design of each IBISCA project. In San Lorenzo, five sites were sampled with one understorey and three canopy cylinders in each, and in Lamington Park four altitudes were each surveyed with one understorey and four canopy transect. Both study sites were sampled during two distinct seasons: August 2003 (rainy season) and May 2004 (end of the short dry season), in Panama; in October 2006 (early wet season) and March-April 2007 (early dry season), in Australia. A short description of the method, which is detailed in Ribeiro and Basset (2007) and Ribeiro et al. (2012), is presented below.

\subsubsection{Sampling Protocol: The Pin-Cylinder Transect}

The canopy cylinder transect is a cylindrical transect which started at the upper canopy and finished at $3 \mathrm{~m}$ above the ground. For the understorey cylinder transect, it followed along an equivalent horizontal transect of $20 \mathrm{~m}$ in Lamington and 30 in San Lorenzo (the average height of these forests, respectively) parallel to and $10 \mathrm{~cm}$ above the soil, thus preventing sampling seedlings. In each transect, a 'sample' consisted of a branch or continuous groups of leaves within the cylinder. From each sample, the total number of leaves, the number of young leaves, the number of buds and active meristems and the number of damaged leaves were counted. Leaf herbivory was taken from counting all leaves with more than $10 \%$ of leaf area lost, estimated visually. Since this figure represents global average leaf area loss in tropical wet forests, leaves scored above this average may be considered "substantially damaged" (Coley and Aide 1991) and the proportion of damaged/total leaves per strata resulted in our estimate of free-feeding herbivory. Healthy leaves were collected for an analysis of specific leaf mass, an indirect measure of sclerophylly. 
Specific mass per leaf area unit (Cooke et al. 1984) was obtained by dividing leaf dry weight by area, using mature leaves collected in 2006. To estimate gall densities, all leaves in a sample with galls, or any gall-like imperfections, were collected and frozen. Galls were opened in the laboratory to evaluate if they were alive or dead and if dead, the cause of death. We analysed the following gall categories: (a) all galls (including galls with live and dead insects; hereafter 'live' and 'dead' galls for sake of brevity); (b) only galls with live larvae; (c) recently hatched galls; and (d) galls with larvae that had died recently by fungal attack (recognized by rotten larvae or the presence of mould) or parasitoid attack (identified by the presence of the parasitoid ecdysis or several small asymmetric apertures in the gall, along with wastes inside).

\subsection{Contrasting Foliage and Gall Distribution in the Panamanian San Lorenzo Forest and in the Australian Lamington Park}

The Panamanian forest had substantially more plants in the understorey than in the canopy, but similarly more foliage in the opposite direction (8.5 times more, Table 8.1). Contrastingly, Lamington subtropical forest had only $50 \%$ more plants in the understorey compared with the canopy, and only 2.5 more leaves in the canopy (Table 8.1). These figures reflect a much denser and entangled forest in Lamington than in San Lorenzo, which had 2.5 plant species per cylinder against 1.3 species in the latter. Hence, it is as if the tropical Panamanian forest was shaped by the top, with the upper canopy species shadowing down the rest of the forest, thus resulting in empty spaces within the forest.

\subsection{San Lorenzo Forest Gall Distribution}

\subsubsection{Gall Distribution Among Tree Species}

Galls were present only in 47 samples and 16 (out of 73) identified host species (Ribeiro and Basset 2007). Overall, 32 gall species were collected, including $59 \%$ of which occurred exclusively in the canopy, $28 \%$ only in the understorey, and $12.5 \%$ found in both habitats. We noted that $81 \%$ of our gall host plants at San Lorenzo have either congenerics $(50 \%)$ or are present $(31 \%)$ in the Brazilian cerrado (Table 8.1), where gall diversity is one of the highest in the world (Price et al. 1998).

Scaling down to leaf level, Ribeiro and Basset (2007) surveyed in average 21,997 leaves per year, of which $2.4 \%$ bore galls in the wet season 2003 and $5.5 \%$ by the end of the dry season, although restricted to fewer trees. However, a similar number of galls were sampled in the two seasons (average 2,507 galls), with $15.6 \%$ of galls 
Table 8.1 Canopy and understorey plant parameters, and gall versus chewing herbivory infestation obtained by understorey-canopy cylinder protocol, in San Lorenzo National Park, Panama, and Lamington National Park, Australia

\begin{tabular}{|c|c|c|}
\hline Forest/gall parameter & San Lorenzo & Lamington park \\
\hline \multirow[t]{4}{*}{ Plant diversity } & 73 plant species & 72 plant species \\
\hline & 50 genera & 61 genera \\
\hline & 31 families & 33 families \\
\hline & 231 sampled plants & 329 sampled plants \\
\hline \multirow[t]{2}{*}{$\begin{array}{l}\text { Plant/foliage } \\
\text { distribution }\end{array}$} & $\begin{array}{l}7.3 \text { more plants in the } \\
\text { understorey than } \\
\text { canopy }\end{array}$ & 1.5 more plants in the understorey than canopy \\
\hline & $\begin{array}{l}8.5 \text { more leaves in } \\
\text { the canopy than } \\
\text { in the understorey }\end{array}$ & $\begin{array}{l}2.5 \text { more leaves in the canopy than the } \\
\text { understorey }\end{array}$ \\
\hline Total sampled leaves & 22,155 sampled leaves & 43,980 sampled leaves \\
\hline $\begin{array}{l}\text { Mean chewing } \\
\text { herbivory }\end{array}$ & $20 \%$ damaged & $35 \%$ damaged \\
\hline \multirow{2}{*}{$\begin{array}{l}\text { Numbers of host } \\
\text { species }\end{array}$} & 16 species & 29 species \\
\hline & $\begin{array}{l}22 \% \text { of total plant } \\
\text { species }\end{array}$ & $40.2 \%$ of total plant species \\
\hline $\begin{array}{l}\text { Mean proportion } \\
\text { of infected leaves } \\
\text { per galls per year }\end{array}$ & $2.4 \%$ infected by galls & $42 \%$ infected by galls \\
\hline $\begin{array}{l}\text { Mean sampled galls } \\
\text { per year }\end{array}$ & 2,540 galls & 7,447 galls \\
\hline \multirow[t]{5}{*}{$\begin{array}{l}\text { Gall distribution } \\
\text { and host species } \\
\text { specifics }\end{array}$} & $\begin{array}{l}31 \% \text { of galled host } \\
\text { species are present } \\
\text { in the cerrado }\end{array}$ & $\begin{array}{l}2006-80 \% \text { of these galls were concentrated } \\
\text { in six host species: Argyrodendron } \\
\text { actinophyllum, Argyrodendron } \\
\text { trifoliolatum, Arytera divaricata, } \\
\text { Caldcluvia paniculosa, Melodinus } \\
\text { australis, Orites excelsa }\end{array}$ \\
\hline & $50 \%$ of galled species & $2007-65 \%$ of galls on Ficus watkinsiana \\
\hline & have congeneric & $18 \%$ on Argyrodendron trifolialatum \\
\hline & cerrado species & $10 \%$ on Arytera divaricata \\
\hline & & $\begin{array}{l}\text { Arytera divaricata - young saplings inflated } \\
\text { the number of galls in the understorey }\end{array}$ \\
\hline
\end{tabular}

with live larvae in wet season against $5.4 \%$ by the end of the dry season. Leaves substantially damaged by free-feeding herbivory were 20 and $17 \%$ of leaves surveyed in the wet and dry seasons, respectively.

\subsubsection{Gall Density, Sclerophylly and Leaf Chewing Distribution}

Regardless of plant taxonomy, leaf sclerophylly increased significantly with sampling height (Fig. 8.1a). The regression supporting such pattern was not affected by sites, or by the distribution of foliage at different canopy strata (Ribeiro and Basset 2007). 
Although there was a high variation in sclerophylly (some understorey leaves being as tough as canopy leaves), canopy leaves were nearly twice more sclerophyllous than understorey leaves. Leaf sclerophylly affected insect herbivory more significantly than foliage density, but in contrasting directions for gall-forming and freefeeding chewing insects. Although the absolute number of chewed leaves was proportional to the total number of leaves available, thus increasing with height, the proportion of chewed leaves decreased significantly with height. This pattern was similar in both sampling seasons (Fig. 8.1b). On the other hand, sclerophylly affected gall density positively, an effect more important than sample height, and more relevant to gall survivorship than oviposition patterns. The average number of live galls collected in the canopy was 13 times greater than in the understorey, a pattern consistent across sites and sampling years (Ribeiro and Basset 2007, Fig. 8.1c). Further, there was a negative relationship between leaf sclerophylly and the proportion of dead galls.

\subsection{Lamington Forest Gall Distribution}

\subsubsection{Gall Distribution Among Tree Species}

In the early wet season, we sampled 59 species of trees and shrubs, from among which 25 species had galls ( $42 \%$ of total). Thirty-five percent of individual sampled plants had galls, reflecting a great concentration of galls on a relatively few hosts. A total of 4,089 galls were sampled in the year out of 61,107 sampled leaves (Table 8.1). From the total of sampled gall in the wet season, $80 \%$ were concentrated in six host species: Argyrodendron actinophyllum Bailey (Edlin), Argyrodendron trifoliolatum F. Muell. (Malvaceae), Arytera divaricata F. Muell. (Sapindaceae), Ackama paniculosa (F. Muell.) Engl. (Cunoniaceae), Melodinus australis (F. Muell.) Pierre (Apocynaceae) and Orites excelsa R. Br. (Proteacae). For the dry season, $65 \%$ of those were collected in only three individual branches of a single Ficus watkinsiana F. M. Bailey (Moraceae) (an average of 16.6 galls per leaf were sampled). Argyrodendron trifoliolatum had $18 \%$ of the remaining galls and A. divaricata accumulated $10 \%$. A gall morphospecies never occurred in different host species and, mostly, hosts held one to two gall morphospecies. In summary, only seven species, or $9.7 \%$ of the total number of identified plants (and $24 \%$ of galled plant species), accumulated the majority of galls observed.

\subsubsection{Gall Density, Sclerophylly and Leaf Chewing Distribution}

A strong positive correlation between leaf height in the canopy and sclerophylly existed in the Lamington forest (Fig. 8.1d), consistent across all altitudes. In the wet season, both total and live galls showed the same distribution pattern, that is, a 


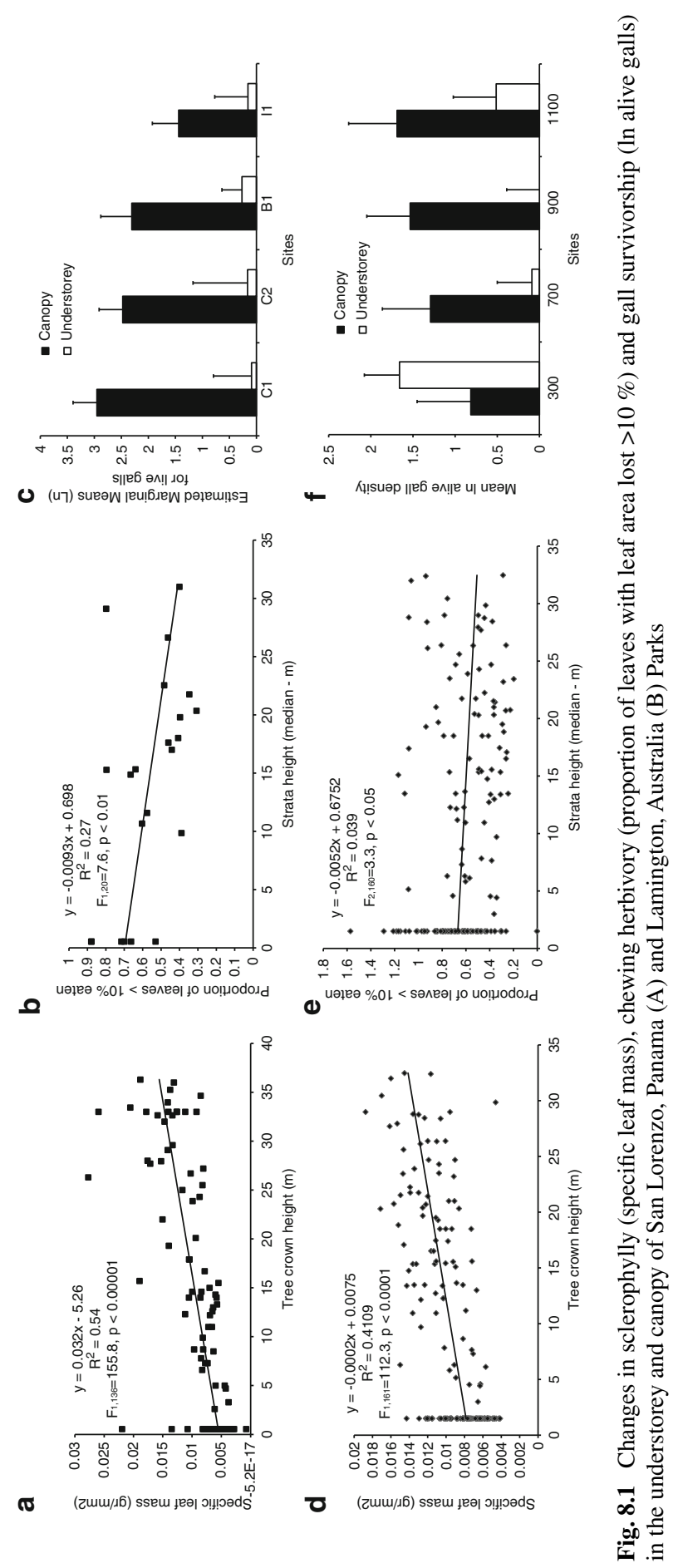


higher density in the canopy than in the understorey. For both total and live galls, altitude and "canopy x understorey" habitats interacted significantly (mixed ANOVA model: Total; $\mathrm{F}_{1 ; 63}=3.57$, p, 0.01; Live galls; $\mathrm{F}_{1 ; 47.3}=3.18, \mathrm{p}<0.03$, Table 8.1, Fig. 8.1f), due to a similar density of galls in the two habitats at $300 \mathrm{~m}$, in contrast to all other altitudes, where galls predominated in the canopy. However, it is important to note that the high understorey gall density at $300 \mathrm{~m}$ was caused by a specific infestation of three sampled saplings of the canopy tree Arytera divaricata and that $19 \%$ of galls found on these hosts were dead. Hence, a clear confounding with a super-host species effect. Although no statistical difference was found when comparing the total galls in the canopy and the understorey at any site, above $300 \mathrm{~m}$ no live galls were found in the understorey (S.P. Ribeiro and R.L. Kitching, unpublished data).

There was a significant response in leaf chewing herbivory with altitude (Type III mixed ANOVA, $\left.\mathrm{F}_{1 ; 160}=3.98, \mathrm{p}<0.001\right)$. As expected, lower, warmer altitudes had more leaf-chewing herbivory activity, with 300 and $700 \mathrm{~m}$ recording the highest rates, $900 \mathrm{~m}$ an intermediate level of herbivory and a significantly lower mean herbivory rate at the $1,100 \mathrm{~m}$ sites (Least Significant Difference post-hoc test, $\mathrm{p}<0.0001$ ). However, no direct sclerophylly effect was found (Multiple regression, $\mathrm{t}$-test on Beta $\mathrm{t}=0.73, \mathrm{p}>0.05$ ). Nevertheless, chewing decreased significantly with forest height, reflecting somehow a pattern indirectly related to habitat sclerophylly, and inverse from that found for gall (Fig. 8.1e). Regardless a low coefficient of determination, the robustness of the sample size allowed the detection of this trend, even though further explanations are needed for the huge overdispersion of chewing in the forest. An obvious factor affecting the pattern was the mountain altitude, as described before. Still, when comparing all leaf herbivory from understorey and canopy, a significantly higher leaf area lost rate was found for the former $\left(\mathrm{t}\right.$-test $\left.\mathrm{t}_{172 ; 0.05}=3.27, \mathrm{p}<0.001\right)$.

\subsection{Global Pattern Versus Biographic Idiosyncrasies: The Role of Gall Host Taxonomy and Phytogeographic Evolution}

Few studies have explored patterns of herbivory distribution based on large samples actually randomized at the scale of the leaf. The use of the canopy-understorey cylinder allowed a proper comparative study on gall distribution between different forests and habitats. Before, a pioneer study from Price et al. (1998) produced a reliable global comparison in gall diversity among ecological communities, showing a strong positive response to sclerophyllous ecosystems. However, fine scale gall ecological responses that may have produced the global pattern were not properly explored, especially in comparisons between habitats within a forest community. Access to high canopies using really comparative sample protocol was needed to provide proper hypotheses test (Ribeiro 2003; Fleck and Fonseca 2007). 
The Panamanian San Lorenzo and the Australian Lamington IBISCA sites presented a very similar number of plant species within the cylinders (72 in Australia compared with 73 in Panama). Such similarity suggests that the number of branches and species found in the same forest volume may differ little between these two ecosystems, despite a much greater leaf density and seasonal variation in Australia (mean values: 43,980 in Australia against 21,997 in Panama). The number of galled plant species in Australia, however, was nearly twice than found in Panama, even though 80-93\% of the gall density was concentrated in just seven host species and caused by an estimated number of only eight species of gall insects, found on those particular hosts.

The fact that Lamington forest was in average a more sclerophyllous vegetation than San Lorenzo and had the double number of galled tree species, suggest the importance of overall plant community sclerophylly in gall establishment and evolution. Such sclerophyllous trait may well relate to the widespread number of gall species in other ecosystems such as the Brazilian cerrado (Fernandes and Price 1992; Ribeiro et al. 1999).

Finally, the prediction from Fernandes (1992) that most frequently attacked and densely infested host species belong to large pantropical families was supported only for Lamington forest, where galls were found in Malvaceae (Argyrodendron), Moraceae (Ficus), Sapindaceae, Apocynaceae and Proteaceae. All these families have more than 60 genera and some (Moraceae) have more than 1,000 species. Ackama paniculata was the only exception to this pattern, belonging to the small, however primitive (pre-Gondwana) Cunoniaceae family which contains only 25 genera. Another interesting case to note is the galled Proteaceae Orites excelsa. This genus has a gall fossil register from the early Cenozoic and is also found in all south continents. Therefore, gall species distribution may have responded to its early radiation, from 115 to 100 million years ago, just before the split of Gondwana (Larew 1986; Tahvanainen and Niemela 1987).

Nevertheless, this pattern was not supported by the Panamanian data (Medianero et al. 2003; Ribeiro and Basset 2007), where most of galls where on species belonging to small families, and thus appears not to be a fundamental mechanism driving gall distributions worldwide. A strongly constrained evolutionary history of the gall-forming guild, related to a restricted number of host species (see Veldtman and McGeoch 2003), may better define a global pattern. Through analysis of the fossil record, Larew (1986) has shown a significant constancy in the gall fauna associated with a number of host species from the late Miocene-Pliocene, 20-13 million years ago. In addition, when analysed at the community level, following random sampling in the vegetation, we found that galls infected only $22 \%$ of sampled tree species in San Lorenzo National Park, and $40.2 \%$ in Lamington Park.

\subsection{Conclusions}

Unknown evolutionary constraints appear to restrict gall-inducing insects from spreading to the whole of the local flora. Although gall taxa diversification seem to respond to host range in an evolutionarily long time (Hardy and Cook 2010), 
radiation after host invasion may be more related to host species life history and ecology rather than to any taxonomic or biochemical traits. For instance, the greater expectation of finding galls in a plant from a large family could be just a neutral consequence of the sheer size of the family. One may suppose that in a large plant family at least some species will have a life history that matches gall adaptation and developmental demands, and thus increases the chance that indeed those plants will be surveyed by most of sampling methods (examples in Santos et al. 2011). Even authors that have been finding a strong relationship between family size and gall diversity in cerrado, such as Araújo (2011), have clearly posed that the event is host specific within a large family, and that has actually little echo at the genera level, for instance.

These life history components favourable to gall invasion are likely to be related to leaf quality/sclerophylly and the subsequent effects on risk of mortality, caused by fungi, parasitoids, or accidental chewing by herbivores. The latter effect was first proposed by Ribeiro and Basset (2007) and is also partially supported by Lamington data, which showed a substantially higher leaf area lost in the understorey compared with the canopy, where most of the galls were found.

Our work filled up a few gaps in cross-ecosystems/continents data, at a scale that allowed us to support or reject some unanswered hypotheses on galls species distribution patterns. Fleck and Fonseca (2007) listed flaws and deficiencies of 13 classic hypotheses on insect diversity distribution when applied to gall species. We may suggest that "taxonomic isolation", "soil fertility", "plant species richness" or "resource concentration" are unlikely to explain gall distribution. In addition, the lack of data on tall tropical forest galls jeopardizes previous negative conclusions on the "architecture complexity" hypothesis. In fact, the latter may be a complementary explanation to the "higrothermal/sclerophylly stress", the one our data corroborate most, along with the Price's (1994) "phylogenetic constraint" hypothesis, not explored by Fleck and Fonseca (2007).

In conclusion, micro-habitat harshness and leaf sclerophylly determine gall insects' oviposition preferences and/or survivorship (Fernandes and Price 1988, 1992; Ribeiro and Basset 2007), although in Lamington National Park these mechanisms were partially masked by a strong host specific association that constrained gall distribution, as well as the strong altitudinal factor. Comparison with San Lorenzo humid closed rainforest suggests the likely existence of a sclerophylly rate threshold above which galls tend to succeed better and spread in the plant community.

Nevertheless, specific evolutionary histories play an equally important role in the global patterns of local gall species richness and abundance. Idiosyncrasies ought to be related to biogeographic regions, and an isolated continent as Australia was indeed expected to reflect Gondwana events. On the contrary, the Neotropical region seems to be mostly influenced by a high number of widely distributed host species, which have a biogeographic range across biomes and sufficiently connected by xeric/canopy habitats. 
Acknowledgements We thank Pro-Natura International, Océan Vert, the Blaise Pascal University (France), the University of Panama and the Smithsonian Tropical Research Institute (STRI) for initiating and organizing the IBISCA-Panama project. Special thanks to the Canopy Crane team and to "Les ACCRO-branchés" for assistance with logistics in the field. O. Calderon and M. Samaniego helped with plant identification, and A. Vieira processes galls. E. Medianero, M. Faria, W. Fernandes, M. Mendonça and O. Lewis discussed some of the ideas presented here. Core funding for IBISCA was provided by SolVin-Solvay, STRI, the United Nations Environment Programme, a Walcott endowment fund grant from the Smithsonian Institution, the European Science Foundation and the Global Canopy Programme. The UFOP Pro-Rectory of Research partly funded this study. We thank also Milton Barbosa for climbing and field services; we are also grateful to S. Curtis, J. Have, S. Maunsell, D. Pamin and K. Yusah for contributions to the field work. The IBISCA Lamington project was funded by a Queensland Government Smart State Grant operated by the Department of State Development, with additional cash support from Griffith University, the Queensland Museum, Queensland Herbarium, Natural Resource Management Queensland, the Queensland National Parks Association and the Global Canopy Programme (Oxford). British Foreign and Commonwealth Office/Post-Graduate Programme in Ecology of Tropical Biomes/UFOP provided the climbing gears and training. Fundação de Amparo à Pesquisa de Minas Gerais and the Brazilian Consul for Science and Technology, CNPq, funded SPR.

\section{References}

Araújo WS (2011) Size, age and composition: characteristics of plant taxa as diversity predictors of gall-midges (Diptera: Cecydomyiidae). Rev Biol Trop 59:1599-1607

Basset Y, Corbara B, Barrios H, Cuenoud P, Leponce M, Aberlenc H-P, Bail J, Bito D, Bridle JR, Castano-Meneses G, Cizek L, Cornejo A, Curletti G, Delabie JHC, Dejean A, Didham RK, Dufrene M, Fagan LL, Floren A, Frame DM, Halle F, Hardy OJ, Hernandez A, Kitching RL, Lewinsohn TM, Lewis OT, Manumbor E, Medianero E, Missa O, Mitchell AW, Mogia M, Novotny V, Odegaard F, Oliveira EG, Orivel J, Ozanne C, Pascal O, Pinzon S, Rapp M, Ribeiro SP, Roisin Y, Roslin T, Roubik DW, Samaniego M, Schmidl J, Sorensen LL, Tischeshkin A, Van Osselaer, Winchester NN (2007) IBISCA-Panama, a large-scale study of arthropod betadiversity and vertical stratification in a lowland rainforest: rationale, field sites and protocols. BullInst R Soc Nat Belg 77:39-69

Basset Y, Cizek L, Cuenoud P, Didham RK, Guilhaumon F, Missa O, Novotny V, Odegaard F, Roslin T, Schmidl J, Tishechkin AK, Winchester NN, Roubik DW, Aberlenc H-P, Bail J, Barrios H, Bridle JR, Castano-Meneses G, Corbara B, Curletti G, Duarte Da Rocha W, De Bakker D, Delabie JHC, Dejean A, Fagan LL, Floren A, Kitching RL, Medianero E, Miller SE, Oliveira E, Orivel J, Pollet M, Rapp M, Ribeiro SP, Roisin Y, Schmidt JB, Sorensen L, Leponce M (2012) Arthropod diversity in a tropical forest. Science 338:1481-1484

Coley PD, Aide TM (1991) Comparison of herbivory and plant defense in temperate and tropical broad-leaved forests. In: Price PW, Lewinsohn TM, Fernandes GW, Benson WW (eds) Plantanimal interaction. Evolutionary ecology in tropical and temperate regions. Wiley, New York, pp 25-49

Cooke FP, Brown JP, Mole S (1984) Herbivory, foliar enzyme inhibitors, nitrogen and leaf structure of young and mature leaves in a tropical forest. Biotropica 16:257-263

Espírito-Santo MM, Fernandes GW (2007) How many species of gall-inducing insects are there on Earth, and where are they? Ann Entomol Soc Am 100:95-99

Fernandes GW (1992) Plant family size and age effects on insular gall-forming species richness. Glob Ecol Biogeogr Lett 2:71-74

Fernandes GW, Price PW (1988) Biogeographical gradients in galling species richness: tests of hypotheses. Oecologia 76:161-167 
Fernandes GW, Price PW (1992) The adaptive significance of insect gall distribution: survivorship of species in xeric and mesic habitats. Oecologia 90:14-20

Fleck T, Fonseca CR (2007) Hipóteses sobre a riqueza de insetos galhadores: uma revisão considerando os níveis intraespecífico, interespecífico e de comunidade. Neotrop Biol Conserv 2:36-45

Hardy NB, Cook LG (2010) Gall-inducing in insects: evolutionary dead-end or speciation driver? BMC Evol Biol 10:257, http://www.biomedcentral.com/1471-2148/10/257. Retrieved on March 2012

Kitching RL, Putland D, Ashton LA, Laidlaw MJ, Boulter SL, Christensen H, Lambkin CL (2012) Detecting biodiversity changes along climatic gradients: the IBISCA Queensland project. Mem Qld Mus 55:235-250

Larew HG (1986) The fossil gall record: a brief summary. Proc Entomol Soc 88:385-388

Medianero E, Barrios H (2001) Riqueza de insectos cecidógenos en el dosel y sotobosque de dos zonas ecológicas en Panamá. Scientia 16:17-42

Medianero E, Valderrama A, Barrios H (2003) Diversidad de insectos minadores de hojas y formadores de agallas en el dosel y sotobosque del bosque tropical. Acta Zool Mex 89:153-168

Medianero E, Paniagua MC, Castano-Meneses G (2010) Comparación temporal de la riqueza y composisión de insectos indutores de agallas en el dosel de un bosque tropical. Rev Mex Biodivers 80:465-472

Mendonça MS Jr (2001) Gall insects diversity patterns: the resource synchronisation hypothesis. Oikos 95:171-176

Price PW (1977) General concepts on the evolutionary biology of parasites. Evolution 31:405-420

Price PW (1994) Phylogenetic constraints, adaptive syndromes, and emergent properties: from individuals to population dynamics. Res Popul Ecol 36:3-14

Price PW, Fernandes GW, Lara ACF, Brawn J, Barrios H, Wright M, Ribeiro SP, Rothcliff N (1998) Global patterns in local number of insect galling species. J Biogeogr 25:581-591

Ribeiro SP (2003) Insect herbivores in the canopies of savannas and rainforests. In: Basset $Y$ et al (eds) Arthropods of tropical forests: spatio-temporal dynamics and resource use in the canopy. Cambridge University Press, Cambridge, pp 348-359

Ribeiro SP, Basset Y (2007) Gall-forming and free-feeding herbivory along vertical gradients in a lowland tropical rainforest: the importance of leaf sclerophylly. Ecography 30:663-672

Ribeiro SP, Braga AO, Silva CHL, Fernandes GW (1999) Leaf polyphenols in Brazilian Melastomataceae: sclerophylly, habitats, and insect herbivores. Ecotropica 5:137-146

Ribeiro SP, da Silva MB Jr, Tagliati MC, Chavana-Bryant C (2012) Vegetation traits and herbivory distribution in an Australian subtropical forest. Mem Qld Mus 55:481-493

Santos JC, Almeida-Cortez JS, Fernandes GW (2011) Diversity of gall-inducing insects in the high altitude wetland forests in Pernambuco, Northeastern Brazil. Braz J Biol 71:47-56

Tahvanainen J, Niemela P (1987) Biogeographical and evolutionary aspects of insect herbivory. Ann Zool Fenn 24:239-247

Veldtman R, McGeoch MA (2003) Gall-forming species richness along a non-scleromorphic vegetation rainfall gradient in South Africa: the importance of plant community composition. Aust Ecol 28:1-13 